\title{
Effect of modified atmosphere packaging on the course of physical and chemical changes in chilled muscle tissue of silver carp (Hypophthalmichthys molitrix, V.)
}

\author{
F. Ježek, H. Buchtová \\ University of Veterinary and Pharmaceutical Sciences Brno, Faculty of Veterinary Hygiene and Ecology, \\ Department of Meat Hygiene and Technology, Palackeho 1-3, 61242 Brno, Czech Republic
}

\begin{abstract}
The effect of two types of modified atmosphere (MA1: $69 \% \mathrm{~N}_{2}, 25 \% \mathrm{CO}_{2}, 5 \% \mathrm{O}_{2}, 1 \% \mathrm{CO}$; MA2: $\left.70 \% \mathrm{~N}_{2}, 30 \% \mathrm{CO}_{2}\right)$ on changes in physical and chemical parameters $\left(\mathrm{pH}, \mathrm{a}_{\mathrm{w}}-\right.$ water activity, TVBN - total volatile basic nitrogen, TMA - trimethylamine, FFA - free fatty acids, PV - peroxide value, TBA - thiobarbituric acid) in muscle tissues of the silver carp was monitored in the study. The samples were stored at temperatures $+2 \pm 2^{\circ} \mathrm{C}$ for 18 days. Changes in gas volumes $\left(\mathrm{CO}_{2}\right.$ and $\left.\mathrm{O}_{2}\right)$ in $\mathrm{MA}_{\mathrm{s}}$ were also monitored. $\mathrm{CO}_{2}$ levels increased in MA1 but decreased in MA2. At the end of 18 days of storage, a significantly $(\mathrm{P}<0.01)$ lower water activity $\left(\mathrm{a}_{\mathrm{w}}\right)$ levels were found in samples packaged under MA1, in contrast to samples packaged under MA2 where water activity values showed considerable fluctuation. Variations in $\mathrm{pH}$ values in the two types of MA showed similar trends. Sample $\mathrm{pH}$ gradually decreased until day 9 of storage. On day 11, muscle tissue $\mathrm{pH}$ increased markedly and then began to decrease again. The overall decrease in $\mathrm{pH}$ values was more profound in samples packaged under MA1. TVBN and TMA levels in samples packaged under the two types of MA remained almost identical until day 9 of the experiment. Later, however, significantly $(\mathrm{P}<0.01)$ higher levels of both parameters were found in muscle tissues packaged under MA1. FFA concentrations in silver carp samples in MA1 were significantly lower $(\mathrm{P}<0.01)$ throughout the experiment. The PV increased significantly in both muscle samples tested. Greater fluctuations in this parameter's values throughout the experiment were observed in samples packaged under MA2. Faster rates of oxidation $(\mathrm{P}<0.01)$ were found in samples packaged under MA1 starting on day 9. Maximum TBA values in MA1 and MA2 were observed on days 14 and 18 of the experiment, respectively. From the course of proteolytic and oxidative changes point of view, the more appropriate combination of gases for silver carp storage seems to be the mixture of $70 \% \mathrm{~N}_{2}$ and $30 \% \mathrm{CO}_{2}$ (MA2), which allows for muscle storage of up to 9 days. We recommend TVBN as a suitable indicator of freshness, and TBA assay as a suitable indicator of the extent of oxidative processes.
\end{abstract}

Key words: freshness, meat oxidation, freshwater fish, chemical changes 


\section{Introduction}

The silver carp (Hypophthalmichthys molitrix, V.) is farmed abundantly mainly in China, where it made up 26.3\% (10,600,000 tonnes) of total fish production in 2005 (Fan et al. 2008). The silver carp was introduced to the Czech Republic in 1964, where it now ranks among the five most commonly raised species of freshwater fish (Pipová 2006, Ženíšková and Gall 2009).

Fish belong to foods with very poor keeping quality. Muscle tissues of fish contain large quantities of water $(60-80 \%)$, have high water activity $\left(\mathrm{a}_{\mathrm{w}}>0.95\right)$, and post-mortem $\mathrm{pH}$ seldom decreases below 6.0. When fish are in cold storage, changes in their physical, chemical, microbiological and sensory characteristics will necessarily take place. In the process of proteolysis, proteins are cleaved into peptides, amino acids, trimethylamine (TMA), ammonia, etc. These products then have an adverse effect on the quality of fish muscle tissue (Ruiz-Capillas and Moral 2001). Hydrolytic changes in lipids cause the release of free fatty acids (FFA). Fish lipids contain large quantities of polyunsaturated fatty acids, which lead to the initiation of oxidation reactions and the formation of hydroperoxides of fatty acids and other (often toxic) secondary oxidation products (Huss 1995). A variety of methods, such as high hydrostatic pressure (Erkan and Üretener 2010), irradiation process (Erkan and Özden 2007), ozonized slurry ice (Campos et al. 2005), super chilled vacuum packaging (Duun and Rustad 2008), edible films and coatings (Vásconez et al. 2009) and others, can be employed to slow down the changes and extend the shelf life.

A combination of packaging under modified atmosphere (MA) and low temperatures $\left(2 \pm 2^{\circ} \mathrm{C}\right)$ is one of the options for extending fish muscle shelf life, its sensory quality, and to extend the range of products (Yesudhason et al. 2009). For packaging under $\mathrm{MA}$, various $\mathrm{CO}_{2}, \mathrm{O}_{2}$ and $\mathrm{N}_{2}$ combinations and ratios are used, depending in particular on fat content in the fish. Less frequently used gases are Ar and CO. While not permitted for food packaging in the EU, carbon monoxide ( $\mathrm{CO}$ ) is nonetheless used in, e.g., Norway and Japan. Carbon dioxide $\left(\mathrm{CO}_{2}\right)$ acts as an antimicrobial agent inhibiting the growth of microorganisms such as Shewanella putrefaciens, Pseudomonas, Vibrio and Aeromonas spp. (Debevere and Boskou 1996, Ravi Sankar et al. 2008). Goulas and Kontominas (2007) reported that packaging under MA may cause a quality deterioration in fish due to the dissolution of $\mathrm{CO}_{2}$ in muscle tissues and the formation of carbonic acid, which causes a decrease in $\mathrm{pH}$, reduction in muscle protein binding capacity, and changes in the odour and colour of the product. Oxygen $\left(\mathrm{O}_{2}\right)$ serves to prevent the growth of anaerobic microorganisms and to oxygenate myoglobin accompanied by the formation of red oxymyoglobin, which is oxygenated during storage to produce red-and-brown to brown metmyoglobin. Nitrogen $\left(\mathrm{N}_{2}\right)$ is an inert gas that retards oxidative rancidity and inhibits the growth of aerobic microorganisms by displacing oxygen from packs. $\mathrm{CO}$ is considered a toxic gas. It binds itself to oxymyoglobin, which is accompanied by the formation of stable cherry-red carboxymyoglobin, which may mask meat spoilage (Ježek and Buchtová 2007, Robertson 2010).

The main aim of the present study was to monitor physical and chemical changes in chilled muscle tissues of silver carp packaged under two different types of modified atmosphere (MA1: $69 \% \mathrm{~N}_{2}, 25 \% \mathrm{CO}_{2}$, $5 \% \mathrm{O}_{2}, 1 \% \mathrm{CO}$; MA2: $70 \% \mathrm{~N}_{2}, 30 \% \mathrm{CO}_{2}$ ) over an 18-day period of storage, and to evaluate the effect of the two atmospheres on selected indicators $\left(\mathrm{CO}_{2}\right.$ and $\mathrm{O}_{2}$ levels in MA, $\mathrm{pH}, \mathrm{a}_{\mathrm{w}}$ - water activity, TVBN - total volatile basic nitrogen, TMA - trimethylamine, FFA - free fatty acids, PV - peroxide value and TBA - thiobarbituric acid value) of post mortem changes in the muscle and on muscle keeping quality.

\section{Materials and Methods}

Silver carp samples were obtained from the Rybníkářství Pohořelice Company, and were processed at the Mušov freshwater fish processing plant using a standard processing procedure. The fish were stunned with electric current before they were killed, scaled and eviscerated. They were then filleted and cut up and chilled $\left(2 \pm 2^{\circ} \mathrm{C}\right)$. The samples were then shipped to the Department of Meat Hygiene and Technology of the University of Veterinary and Pharmaceutical Sciences in Brno without any interruption in the cool chain. One batch of samples was packaged under MA1 $\left(69 \% \mathrm{~N}_{2}, 25 \% \mathrm{CO}_{2}, 5 \% \mathrm{O}_{2}, 1 \% \mathrm{CO}\right)$ and the other batch under MA2 $\left(70 \% \mathrm{~N}_{2}, 30 \% \mathrm{CO}_{2}\right)$ using the VAC-STAR S 223 chamber packaging machine (VAC-STAR AG, Switzerland) allowing for packaging under MA gases. The packaging sheet was Amilen PA/PE 20/60 (VF Verpackungen GmbH, Germany) made of polyamide, which is very little permeable to $\mathrm{O}_{2}$, and polyethylene, which is relatively permeable to $\mathrm{O}_{2}$. The sheet permeability declared by the manufacturer at $23^{\circ} \mathrm{C}$ is $50 \mathrm{~cm}^{3} \cdot \mathrm{m}^{-2}$ in 24 hours. Packaged samples were stored in a cooling chamber with temperature control $\left(2 \pm 2^{\circ} \mathrm{C}\right)$.

A total of 192 samples packaged under MA1 and 96 samples packaged under MA2 from 36 silver carp cuts were examined. Samples were analyzed on days 1 , $4,7,9,11,14,16$ and 18 of storage. $\mathrm{O}_{2} / \mathrm{CO}_{2}$ levels in 
packages were monitored using a CheckPoint (PBI-Dansensor, Denmark) analyser. Water activity $\mathrm{a}_{\mathrm{w}}$ of samples was determined using a LabMaster-aw instrument (Novasina Ltd., Switzerland). The $\mathrm{pH}$ values of silver carp samples were measured using the inoLab pH 730 digital pH-metre (WTW GmbH, Germany). The total volatile basic nitrogen (TVBN) was determined by direct distillation followed by titration on a Kjeltec 2300 (FOSS, Sweden). Trimethylamine (TMA) was determined using the same method as for TVBN determination after formaldehyde was added to samples to unbind primary and secondary amines. Free fatty acids (FFA) and peroxides were determined after fat extraction with diethyl ether. FFA were determined in accordance with CSN ISO 660. Peroxide values were determined by a modified method according to CSN ISO 3960. The thiobarbituric acid assay (TBA) value was determined by the distillation method (Castellini et al. 2002) and oxidation products were quantified as malondialdehyde (MDA) equivalents.

Results of the analyses were statistically evaluated using a one-factor analysis of the ANOVA programme (Microsoft Office EXCEL 2007).

\section{Results}

The composition of the two types of modified atmosphere changed significantly $(\mathrm{P}<0.01)$ in the course of the experiment. The $\mathrm{CO}_{2}$ level in MA1 increased from $22.96 \pm 0.48 \%$ (day 1 ) to $26.58 \pm 0.41 \%$ (day 18) in contrast with MA2, where it decreased from $24.99 \pm 2.92 \%$ (day 1 ) to $21.25 \pm 1.01 \%$ (day 18 ). Changes were also recorded in concentrations of oxygen. At the end of the experiment, $\mathrm{O}_{2}$ concentrations in MA1 decreased significantly $(\mathrm{P}<0.01)$ to almost zero $(0.02 \pm 0.06 \%)$. On the other hand, $\mathrm{O}_{2}$ was detected $(0.14 \pm 0.13 \%)$ in MA2, where it originally was not applied at all.

Water activity $\mathrm{a}_{\mathrm{w}}$ of the two samples (MA1: 0.984 \pm 0.004, MA2: $0.981 \pm 0.001)$ differed significantly $(\mathrm{P}<0.05)$ on day 1 of the experiment. Also different was further development of the parameter. While $\mathrm{a}_{\mathrm{w}}$ values of samples stored in MA2 showed greater fluctuations and remained almost unchanged on the last day of the experiment $(0.981 \pm 0.003), a_{w}$ value of samples stored in MA1 decreased significantly ( $\mathrm{P}$ $<0.01$ ) during storage to $0.979 \pm 0.005$.

Although $\mathrm{pH}$ values in samples packaged under both types of MA showed a similar trend, the decrease in $\mathrm{pH}$ values was more pronounced in samples stored in MA1. Initial pH values of silver carp muscle tissues packaged in the two types of MA were practically identical (MA1: $6.17 \pm 0.08$; MA2: $6.17 \pm 0.03$ ).
Significant $(\mathrm{P}<0.01)$ acidification occurred between days 1 and 4 of the experiment in both samples monitored, which became gradually more pronounced until day 9 of the experiment in samples packaged under MA1 in contrast to those stored in MA2, where $\mathrm{pH}$ fluctuated noticeably over that period. On day 11 of the experiment, $\mathrm{pH}$ levels in both samples monitored showed a statistically significant increase (MA1: $\mathrm{P}<0.01$, MA2: $\mathrm{P}<0.05$ ). Over the following days of the experiment, muscle became gradually more acidified, and the process was much more intense $(\mathrm{P}<0.01)$ in samples packaged under MA1 $(5.99 \pm 0.09)$ than in the case of MA2 $(6.12 \pm 0.02)$ (Fig. 1).

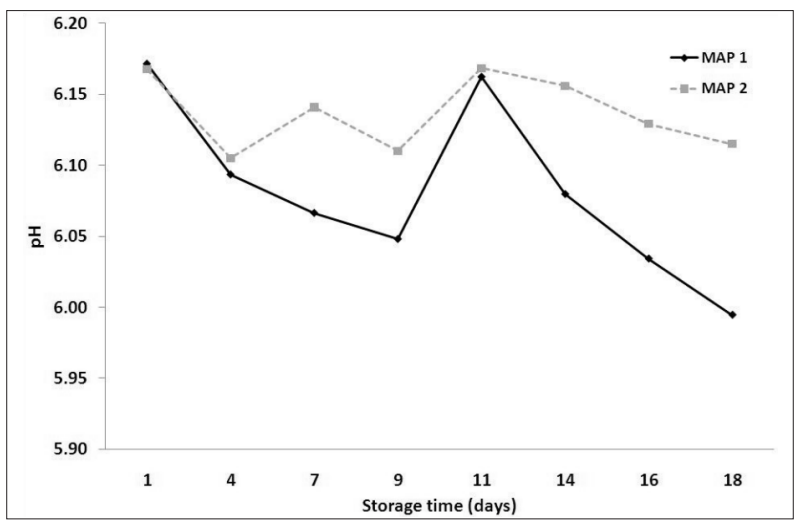

Fig. 1. Acidification of chilled silver carp muscle stored in two different modified atmospheres.

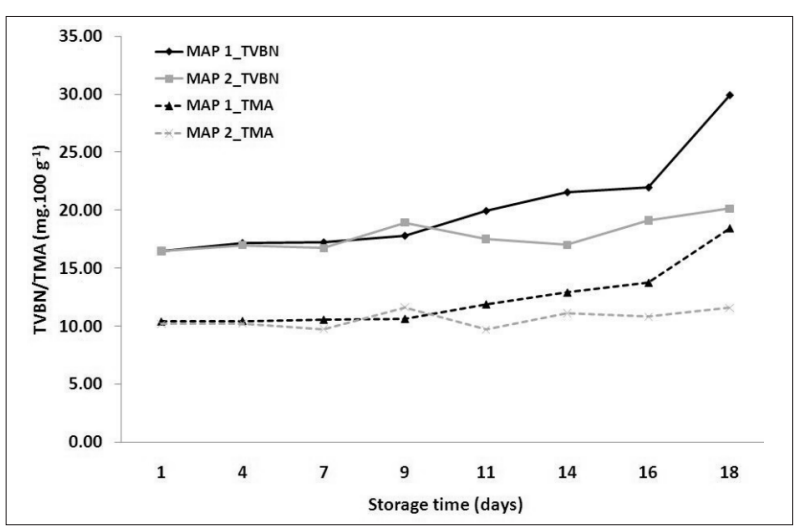

Fig. 2. TVBN and TMA concentrations during cold storage of silver carp in two different modified atmospheres.

At the beginning of the experiment, concentrations of low-molecular N-substances (TVBN and TMA) in muscle samples in both experimental groups were practically identical $(\mathrm{P}>0.05)$. Until day 7 of storage, concentrations of these degradation products remained mostly unchanged. On experiment day 9, their concentrations in samples packaged under MA1 
were lower than in those packaged under MA2. During further storage, higher concentrations of these substances were found only in samples stored in MA1. Towards the end of the experiment, samples in MA1 showed a significant $(\mathrm{P}<0.01)$ increase in TVBN and TMA concentrations of up to $29.92 \pm 6.55$ and 18.45 $\pm 3.64 \mathrm{mg} \cdot 100 \mathrm{~g}^{-1}$, respectively. TVBN and TMA levels in samples packaged under MA2 did not change during the experiment as much as those in samples packaged under MA1, and were considerably lower (P $<0.01$; TVBN $20.15 \pm 0.74$; TMA $11.57 \pm 1.06$ $\mathrm{mg} \cdot 100 \mathrm{~g}^{-1}$ ) at the end of the experiment (Fig. 2).

FFA concentrations in samples packaged under MA1 were significantly $(\mathrm{P}<0.01)$ lower and fluctuated less throughout the experiment. Compared with day 1, FFA concentrations in MA1 samples at the end of the experiment were only slightly higher $(2.80 \pm 0.82 \%$ total fat as oleic acid). In MA2 samples, FFA concentrations fluctuated markedly. The highest values of this parameter (in total fat as oleic acid) were observed at the beginning $(6.12 \pm 1.43)$ and at the end $(7.48 \pm 2.32)$ of the experiment (Fig. 3$)$.

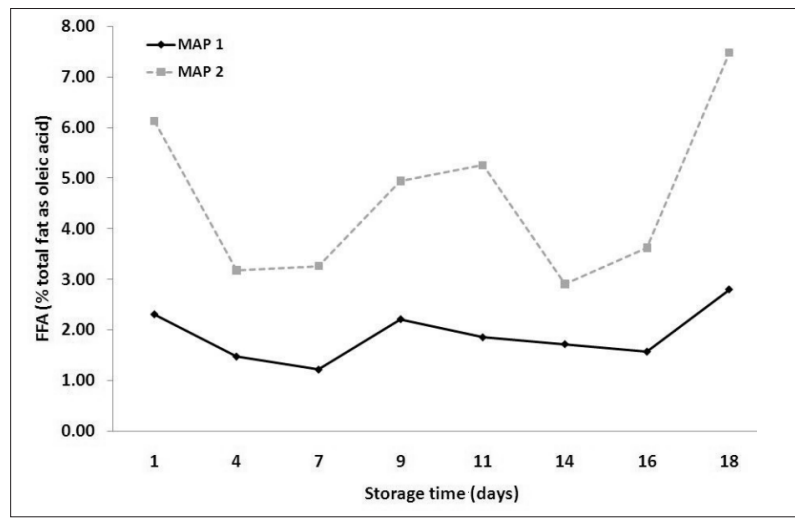

Fig. 3. FFA concentrations during cold storage of silver carp in two different modified atmospheres.

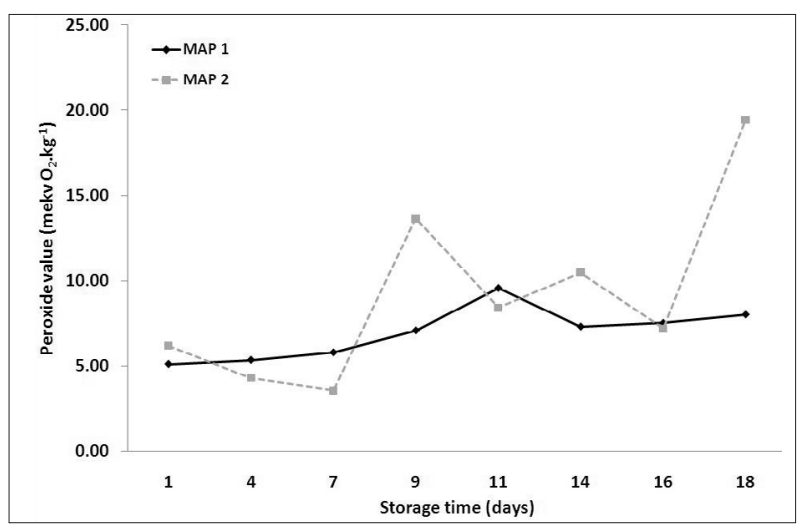

Fig. 4. Primary oxidation of chilled silver carp muscle stored in two different modified atmospheres.
At the beginning of the experiment, peroxide values (in mekv $\mathrm{O}_{2} \cdot \mathrm{kg}^{-1}$ ) in MA1 and MA2 samples were practically identical $(5.10 \pm 1.80$ and $6.19 \pm 7.24$, respectively) $(\mathrm{P}>0.05)$. In the course of storage, values of this parameter fluctuated more in samples packaged under MA2, where the highest values (in mekv $\left.\mathrm{O}_{2} \cdot \mathrm{kg}^{-1}\right)$ were observed on days $9(13.65 \pm 2.91)$ and $18(19.24 \pm 2.54)$ of monitoring. In samples packaged under MA1, peroxide values increased gradually to reach $9.56 \pm 1.99 \mathrm{mekv} \mathrm{O}_{2} \cdot \mathrm{kg}^{-1}$ by day 11 of the experiment. There was a significant $(\mathrm{P}<0.01)$ decrease in peroxide values between days 11 and 14 . Differences between other days were not significant (Fig. 4).

Initial TBA concentrations were higher $(19.25$ $\left.\pm 8.41 \mathrm{mg} \cdot \mathrm{kg}^{-1}\right)$ in muscle tissues packaged under MA1 than in samples stored in MA2 (12.08 \pm 2.54 $\left.\mathrm{mg} \cdot \mathrm{kg}^{-1}\right)$. Secondary oxidation processes were more intense $(\mathrm{P}<0.01)$ in samples packaged under MA1 from the beginning of the experiment until day 9 of storage. In the course of further monitoring, TBA levels in muscle tissue of those samples continued to grow moderately. The highest TBA value was reached on day 14 of the experiment $\left(43.42 \pm 18.31 \mathrm{mg} \cdot \mathrm{kg}^{-1}\right)$. From then on, TBA levels in samples packaged under MA1 gradually decreased. TBA levels in silver carp samples stored in MA2 did not reach their maximum $\left(34.14 \pm 7.09 \mathrm{mg} \cdot \mathrm{kg}^{-1}\right)$ before the end of the experiment (Fig. 5).

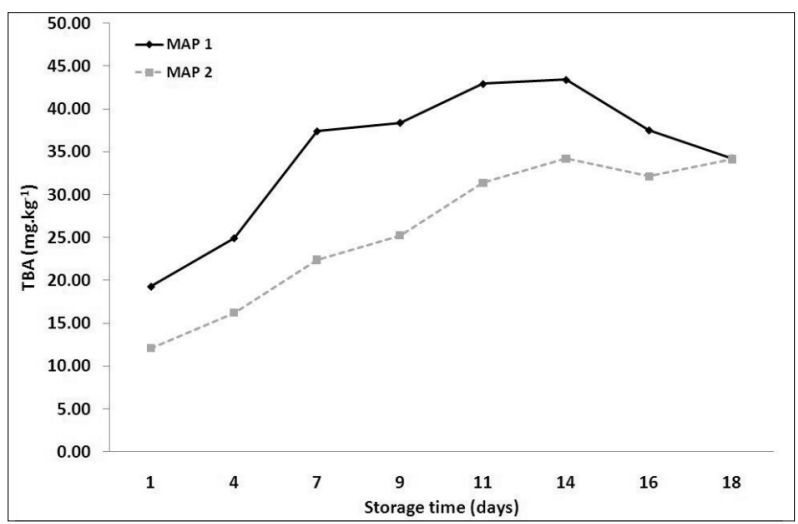

Fig. 5. Secondary oxidation of chilled silver carp muscle stored in two different modified atmospheres.

\section{Discussion}

Spoilage of fresh fish is a complicated process which consists of several mutually interconnected systems, in which some of them are suppressed by others. The main factors contributing to spoilage are protein degradation with a subsequent formation of various products such as hypoxanthine and trimethylamine, development of oxidative fat rancidity and enzymatic 
activity of contaminating microorganisms (Abbas et al. 2009).

The use of a modified atmosphere (MA) for food packaging has been known for quite some time. The main active component of $\mathrm{MA}$ is $\mathrm{CO}_{2}$, which is readily soluble in water, and carbonic acid is formed from the reaction. $\mathrm{CO}_{2}$ concentrations of 40 to $60 \%$ help to keep the fresh fish flavour in many fish species, but higher concentrations may, however, cause the packaging to collapse before the fish is considered unacceptable. This can be prevented by exposing the fish to $\mathrm{CO}_{2}$ before they are packaged under MA (Robertson 2010).

In the case of MA1, $\mathrm{CO}_{2}$ concentrations in packages decreased until day 4, which was caused by $\mathrm{CO}_{2}$ dissolution in tissue fluids. The subsequent $\mathrm{CO}_{2}$ increase in packages was due to bacterial and enzymatic activity (Wang et al. 2008, Yesudhason et al. 2009). The small amount of $\mathrm{O}_{2}(5 \%)$ in MA1 was used up in biochemical reactions and microbial activity. In MA2, which contained no $\mathrm{O}_{2}$ and $30 \%$ of $\mathrm{CO}_{2}$, microorganism activity was probably more inhibited, and $\mathrm{CO}_{2}$ decreased as a consequence of the gas dissolution into the present liquid (Ruiz-Capillas and Moral 2001), with packaging permeability also possibly playing a role in the case of both MA types (Fernández et al. 2009). When packaged under MA1 (with CO), samples turned red-and-pink, and retained the colour until the end of the experiment (day 18). The disadvantage of $\mathrm{CO}$ is its bad reputation with consumers as a potentially dangerous gas, and the fact that products may look fresh although in fact they may contain large quantities of bacteria and may be spoiled (Cornforth and Hunt 2008).

Water activity is ranked by food professionals among the important indicators in the control of food development, quality and safety, and it is measured primarily where microbial spoilage may occur. Water activity is frequently used as a critical control point in the Hazard Analysis and Critical Control Points (HACCP) programme (Abbas et al. 2009). The higher the $\mathrm{a}_{\mathrm{w}}$, the higher the rate of lipid oxidation (Barbosa-Cánovas et al. 2007). Although fluctuating trends were observed in both MA in our experiment, no significant difference $(\mathrm{P}>0.05)$ between MA1 and MA2 was found on the last experiment day. As with silver carp stored in MA2, changes in $\mathrm{a}_{\mathrm{w}}$ observed in meagre (Argyrosomus regius) during 18-day cold storage were only insignificant (Hernández et al. 2009).

The lowest $\mathrm{pH}$ values ascertained in silver carp muscle (MA1: $5.99 \pm 0.09$; MA2: $6.11 \pm 0.03$ ) testify to very low glycogen levels in fish muscle tissues, similar to the study by Ježek and Buchtová (2011). The initial drop in $\mathrm{pH}$ (by day 9 of storage) in both types of MA is usually associated with the dissolution of $\mathrm{CO}_{2}$ in muscle tissues. The subsequent increase in $\mathrm{pH}$ is usually associated with the production of basic components such as ammonia, dimethylamine, trimethylamine, other biogenic amines, and is also considered the result of microbial spoilage (Goulas and Kontominas 2007, Fan et al. 2008). Further acidification may be caused by lactacidogenic bacteria, which, in vacuum packaging and MA, effectively inhibit gram-negative aerobic bacteria (mainly pseudomonads), and they become predominant as their numbers increase in the course of the storage period (Leroi 2010). The lower $\mathrm{pH}$ in muscle tissue in MA1 (Fig. 1) reflects $\mathrm{CO}_{2}$ increases in the course of storage.

Total volatile basic nitrogen (TVBN) is one of the major indicators of freshness. It is produced during degradation of protein and non-protein nitrogen components, caused mainly by microorganisms. Starting on day 9 of the experiment, the composition of MA2 significantly $(\mathrm{P}<0.05)$ slowed TVBN formation. Significant $(\mathrm{P}<0.01)$ differences between MA1 and MA2 towards the end of storage are mainly the result of the protective effect of $\mathrm{CO}_{2}$ in $\mathrm{MA} 2$ due to its bacteriostatic properties, but also of the presence of $\mathrm{O}_{2}$ in MA1, which makes the growth of aerobic bacteria possible and subsequently accelerates spoilage leading to TVBN accumulation (Goulas and Kontominas 2007). Depending on fish species, type of treatment and processing, $25-40 \mathrm{mg} \mathrm{TVBN} \cdot 100 \mathrm{~g} \mathrm{~g}^{-1}$ is considered the maximum limit (Fan et al. 2008). The Commission Regulation (EC) 2074/2005 regards as unfit for human consumption those fish (Sebastes spp., Salmo salar, species belonging to Pleuronectidae, Merlucidae and Gadidae families) where organoleptic assessment has raised doubts as to their freshness and chemical checks reveal that TVBN levels (25 to 35 $\mathrm{mg} \cdot 100 \mathrm{~g}^{-1}$ ) have been exceeded. The maximum TVBN levels that we found (day 18) in silver carp muscle were within both above limits (MA1: 29.92 \pm 6.55; MA2: $20.15 \pm 0.74 \mathrm{mg} \cdot 100 \mathrm{~g}^{-1}$; Fig. 2), and were lower than those in silver carp in simple packaging $\left(33.89 \pm 9.08 \mathrm{mg} \cdot 100 \mathrm{~g}^{-1}\right)$ (Ježek and Buchtová 2011). It is important to bear in mind that samples must meet sensory parameters used primarily for freshness assessment.

TMA levels showed a trend similar to that of TVBN levels. Starting on day 11 of storage, higher $(\mathrm{P}<0.01)$ TMA levels were ascertained in MA1 samples. Lower TMA levels in MA2 can also be the result of reduced growth of aerobic, gram-negative bacteria, including Shewanella putrefaciens bacteria that reduce trimethylamine oxide (TMAO) (Yesudhason et al. 2009). TMA levels in fish depend on the species of fish, climatic and storage conditions, as well as on the harvest area (Robertson 2010). Although 
TMA levels are not regulated by legislation, Yesudhason et al. (2009) mention $10-15 \mathrm{mg} \cdot 100 \mathrm{~g}^{-1}$ as the upper limit for TMA concentration in chilled fish. In the case of MA1, that limit was exceeded on day 18 $\left(18.45 \pm 3.64 \mathrm{mg} \cdot 100 \mathrm{~g}^{-1}\right)$, but was never throughout the experiment exceeded in MA2 (Fig. 2). Concentrations of TMA, which is responsible for the fishy odour, could be suitable as an index of spoilage but not an index of freshness (Hernández et al. 2009).

It is well-known that free fatty acids (FFA) are products of enzymatic hydrolysis of esterified lipids. FFA may also take part in a reaction with myofibrillar proteins, and enhance protein aggregation (Özyurt et al. 2009, Bahmani et al. 2011). In our experiment, significant $(\mathrm{P}<0.01)$ differences in FFA levels between MA1 and MA2 were observed from day 1, with higher levels of FFA being ascertained in MA2 samples throughout the experiment (Fig. 3). This can be explained by a rapid FFA conversion to oxidation products (hydroperoxides, cyclic peroxides, endoperoxides, epoxy acids, aldehydes, oxoacids and others) due to the presence of $\mathrm{O}_{2}$ in MA1. Fagan et al. (2004) found higher FFA concentrations in fish muscle packaged under MA right at the beginning of experiment compared with fish exposed to air during storage. FFA may have a pro-oxidant effect on lipid matter, which is attributed to the catalytic effect of the carboxyl group on the formation of free radicals in the decomposition of hydroperoxides. Some authors (Özyurt et al., 2009 Bahmani et al. 2011) believe that there is a direct relationship between FFA formation and the loss of freshness in fish, and a significant effect on the sensory quality of fish. Fagan et al. (2004), on the other hand, claim that FFA levels ascertained have no effect on sensory scores.

Lipid oxidation is often the main reason for the shorter shelf life of fish or fish products. Lipid oxidation in fish depends on several factors, such as fish species, storage temperature, lipid composition, etc. (Bahmani et al. 2011). The peroxide value (PV) was used to determine primary products of oxidation, mainly hydroperoxides. The progress of primary lipid oxidation was rather erratic, particularly in MA2. Similar fluctuations in PV have been reported by some other authors (Özyurt et al. 2009, Bahmani et al. 2011, Chaijan 2011, Ježek and Buchtová 2011). Chaijan (2011) hypothesizes that initial PV indicates oxidation during handling and processing, with competitive reactions and an increase in TBA values being responsible for the subsequent drop in PV. PV cannot be considered a suitable fish muscle freshness indicator (Ježek and Buchtová 2007).

TBA is a broadly used indicator to determine the degree of secondary lipid oxidation. An increase in TBA values is initially caused by MDA production, and its subsequent decrease depends on the production of other secondary products of lipid oxidation (Bahmani et al. 2011). Relatively high TBA values at the beginning of the experiment indicate intense oxidation activity already during processing and packaging. During the storage period, the positive influence of MA2 became apparent. In contrast to MA1, MA2 contained no $\mathrm{O}_{2}$, which slowed the rate of oxidation reactions. Not only $\mathrm{O}_{2}$ but some bacterial enzymes may also participate in oxidation (Hernández et al. 2009). Huss (1995) recorded significant positive correlations between TBA and numbers of microorganisms $(\mathrm{r}=0.94-0.96)$, and also between TBA and sensory evaluation $(\mathrm{r}=0.82-0.98)$. TBA is a more suitable indicator of the degree of fish muscle oxidation than PV. MDA may, however, interact with other components (nucleosides, nucleic acids, proteins and other aldehydes) and thus TBA value need not always accurately reflect the current level of lipid oxidation (Özyurt et al. 2009). During secondary oxidation of lipids, substances of foul odour or taste are often produced. Some such substances may participate in changes to the texture when they form covalent bonds with muscle proteins (Huss 1995). Sensory assessment may then be decisive for the determination of freshness or usability of fish muscle.

\section{Conclusions}

Packaging silver carp under MA slowed mainly proteolytic reactions. TVBN and TMA levels are suitable indicators for the determination of freshness and shelf life. According to those indicators, MA2 (70\% $\mathrm{N}_{2}, 30 \% \mathrm{CO}_{2}$ ) seems to be a more suitable MA for silver carp packaging. FFA and PV are not suitable indicators of keeping quality of fresh water fish because they are converted to other compounds during cold storage and their concentrations show considerable fluctuations. TBA value is a suitable indicator of the extent of oxidation processes in fish muscle tissue. In view of intense oxidative activity, we recommend that silver carp be packaged under MA2 without $\mathrm{O}_{2}$. With respect to the primary sensory assessment, it was determined that the shelf life of silver carp packaged under MA1 and MA2 was 7 and 9 days, respectively, the maximum TVBN value $20 \mathrm{mg} \cdot 100 \mathrm{~g}^{-1}$ and the maximum TBA value $25 \mathrm{mg} \cdot \mathrm{kg}^{-1}$.

\section{Acknowledgements}

Financial support for this study was provided by the Ministry of Education, Youth and Sports of the Czech Republic (Research Plan MSM6215712402). 
The authors are also grateful to all the staff of the Rybníkářství Pohořelice Company for their kind help in processing the fish and their overall technical assistance.

\section{References}

Abbas KA, Saleh AM, Mohamed A, Lasekan O (2009) The relationship between water activity and fish spoilage during cold storage: A review. J Food Agr Env 7: 86-90.

Bahmani ZA, Rezai M, Hosseini SV, Regenstein JM, Böhme K, Alishahi A, Yadollahi F (2011) Chilled storage of golden grey mullet (Liza aurata). LWT-Food Sci Technol 44: 1894-1900.

Barbosa-Cánovas GV, Fontana AJ, Schmidt SJ, Labuza TP (2007) Water activity in foods. Fundamentals and applications. Blackwell Publishing Ltd, USA, p 435.

Campos CA, Rodríquez O, Losada V, Aubourg SP, Barros-Velázquez $\mathrm{J}$ (2005) Effects of storage in ozonised slurry ice on sensory and microbial quality of sardine (Sardina pilchardus). Int J Food Microbiol 103: 121-130.

Castellini C, Mugnai C, Dal Bosco A (2002) Effect of organic production system on broiler carcass and meat quality. Meat Sci 60: 219-225.

Chaijan M (2011) Physicochemical changes of tilapia (Oreochromis niloticus) muscle during salting. Food Chem 129: 1201-1210.

Cornforth DP, Hunt MC (2008) Low-oxygen packaging of fresh meat with carbon monoxide. AMSA White Paper Series 2: 1-10.

Debevere J, Boskou G (1996) Effect of modified atmosphere packaging on the TVB/TMA-producing microflora of cod fillets. Int J Food Microbiol 31: 221-229.

Duun AS, Rustad T (2008) Quality of superchilled vacuum packed Atlantic salmon (Salmo salar) fillets stored at -1.4 and $-3.6^{\circ} \mathrm{C}$. Food Chem 106: 122-131.

Erkan N, Özden Ö (2007) The changes of fatty acid and amino acid compositions in sea bream (Sparus aurata) during irradiation process. Radiat Phys Chem 76: 1636-1641 .

Erkan N, Üretener G (2010) The effect of high hydrostatic pressure on the microbiological, chemical and sensory quality of fresh gilthead sea bream (Sparus aurata). Eur Food Res Technol 230: 533-542.

Fagan JD, Gormley TR, Ut Mhuircheartaigh MM (2004) Effect of modified atmosphere packaging with freeze-chilling on some quality parameters of raw whiting, mackerel and salmon portions. Inn Food Sci Emerg Technik 5: 205-214.

Fan W, Chi Y, Zhang S (2008) The use of tea polyphenol dip to extend the shelf life of silver carp (Hypophthalmicthys molitrix) during storage in ice. Food Chem 108: 148-153.

Fernández K, Aspe E, Roeckel M (2009) Shelf-life extension on fillets of Atlantic Salmon (Salmo salar) using natural additives, superchilling and modified atmosphere packaging. Food Control 20: 1036-1042.

Goulas AE, Kontominas MG (2007) Effect of modified atmosphere packaging and vacuum packaging on the shelf life of refrigerated chub mackerel (Scomber japonicus): biochemical and sensory attributes. Eur Food Res Technol 224: 545-553.

Hernandez MD, López MB, Älvarez A, Ferrandini E, García García B, Garrido MD (2009) Sensory, physical, chemical and microbiological changes in aquacultured meagre (Argyrosomus regius) fillets during ice storage. Food Chem 114: 237-245.

Huss HH (1995) Quality and quaity changes in fresh fish. FAO Fisheries Technical Paper-348. Food and Agriculture Organization of the United Nations, Rome.

Ježek F, Buchtová H (2007) Physical and chemical changes in fresh chilled muscle tissue of common carp (Cyprinus Carpio L.) packed in modified atmosphere. Acta Vet Brno 76: S83-S92.

Ježek F, Buchtová H (2011) Physicochemical changes of chilled simple and vacuum packaged muscle tissue of silver carp (Hypophthalmichthys molitrix, V.). Fleischwirtschaft 1: 94-98.

Leroi F (2010) Occurence and role of lactic acid bacteria in seafood products. Food Microbiol 27: 698-709.

Özyurt G, Kuley E, Özkütük S, Özogul F (2009) Sensory, microbiological and chemical assessment of the freshness of red mullet (Mullus barbatus) and golband goatfish (Upeneus moluccensis) during storage in ice. Food Chem 114: 505-510.

Pipová M, Buchtová H, Cabadaj R, Gima J, Hanzel S, Iglovská N, Kantíková M, Kohút J, Košuth P, Kozák A, Nagy J, Pliešovský J, Rajský D, Sokol J, Steinhauserová I, Večerek V (2006) Hygiene and processing technology of freshwater and marine fish (In Slovak. In Czech). University of Veterinary Medicine and Pharmacy in Košice, Košice.

Ravi Sankar CN, Lalitha KV, Jose L, Manju S, Gopal TKS (2008) Effect of packaging atmosphere on the microbial attributes of pearlspot (Etroplus suratensis Bloch) stored at $0-2^{\circ} \mathrm{C}$. Food Microbiol 25: 518-528.

Robertson GL (2010) Food Packaging and Shelf Life. A Practical Guide. CRC Press, Boca Raton.

Ruiz-Capillas C, Moral A (2001) Changes in free amino acids during chilled storage of hake (Merluccius merluccius, L.) in controlled atmospheres and their use as a quality control index. Eur Food Res Technol 212: 302-307.

Vásconez MB, Flores SK, Campos CA, Alvarado J, Gerschenson LN (2009) Antimicrobial activity and physical properties of chitosan-tapioca starch based edible films and coatings. Food Res Int 42: 762-769.

Wang T, Sveinsdóttir K, Magnxsson H, Martinsdóttir E (2008) Combined application of modified atmosphere packaging and superchilled storage to extend the shelf life of fresh cod (Gadus morhua) loins. J Food Sci 73: S11-19.

Yesudhanson P, Gopal TKS, Ravishankar CN, Lalitha KV, Kumar KNA (2009) Effect of modified atmosphere packaging on chemical, textural, microbiological and sensory quality of seer fish (Scomberomorus commerson) steaks packaged in thermoformed trays at $0-2^{\circ} \mathrm{C}$. J Food Process Pres 33: 777-797.

Ženíśková H, Gall V (2009) Situation and outlook report. Fish (In Czech). Ministry of Agriculture, Prague. 